\title{
Tertius Integration for Isis Terrorism Prevention in Indonesia: A Study of Structural Holes Theory
}

\author{
Agus Surya Bakti¹, Hafied Cangara1, Dwia Aries Tina Palubuhu', Eriyanto² \\ ${ }^{1}$ Universitas Hasanuddin, Makassar, Indonesia \\ ${ }^{2}$ Universitas Indonesia, Jakarta, Indonesia \\ Email: agus84sb@gmail.com, cangara_hafied@yahoo.com,dwiatn@yahoo.com, eriyanto2001@gmail
}

How to cite this paper: Bakti, A. S., Cangara, H., Palubuhu, D. A. T., \& Eriyanto (2022). Tertius Integration for Isis Terrorism Prevention in Indonesia: A Study of Structural Holes Theory. Open Journal of Social Sciences, 10, 72-83.

https://doi.org/10.4236/jss.2022.101006

Received: November 27, 2021

Accepted: January 10, 2022

Published: January 13, 2022

Copyright $\odot 2022$ by author(s) and Scientific Research Publishing Inc. This work is licensed under the Creative Commons Attribution International License (CC BY 4.0).

http://creativecommons.org/licenses/by/4.0/

\begin{abstract}
This article discusses the study of communication networks of ISIS groups in Indonesia located in three major cities (Poso, Jakarta, and Surabaya) using the Structural Holes theory to formulate a strategy to prevent ISIS terrorism by focusing on the integration of the role of the most important actor (tertius) as an alternative to counter terrorism to the Indonesian government. This research uses mixed methods research; it is a procedure for collecting, analyzing, and mixing quantitative and qualitative methods in a study or series of studies to understand the research problem and to measure the level of cohesion of ISIS network members and view their network map; the data in the network using data analysis method processed with UCINET-Draw. The finding of study that ISIS terror threat still needs to be watched out for, including by the Indonesian government. ISIS is known as a network terrorist group (net-terrorism) that moves through the network, therefore a study that focuses on the network is needed to dissect the ISIS group and then determine the pattern of handling it so that it does not become a threat to the community. In this case, the Indonesian government can play the role of tertius who stands in an integrated position to exploit the flow of information in the ISIS network in Indonesia in the context of preventing terrorism. In this context, as tertius, the government can carry out its function in fewer than two conditions, namely: when there is competition between two parties fighting for the same information, the tertius can act as controller by determining who will be given the information. Second, if both parties are in a conflict position, tertius can change the role of being a mediator whose function is to find a resolution to reduce conflict and share information as much as possible according to their respective portions.
\end{abstract}




\section{Keywords}

Tertius, ISIS, Terrorism, Social Network Strategy, Tertius Strategy

\section{Introduction}

ISIS is a digital-aged terrorism group that was born and raised through the role of the internet. Their violent teachings are deposited and disseminated through the digital world. Using internet, the ISIS group runs its organization, starting from the spread of teachings, recruitment, to the execution of terror attacks (Speckhard, 2020). In Indonesia, the ISIS group made its terror debut in an attack by detonating a bomb in the Thamrin area of Jakarta on January 14, 2016. Although this attack took place almost six years ago, it still leaves a mystery that has attracted various studies (Fenton \& Price, 2016). As one of the reasons, the ISIS group moves with different attack patterns and network organization.

One of the facts revealed in the field of the attack case was the involvement of actors who were serving time in prison, Aman Abdurrahman, who at that time was languishing in the Nusa Kambangan prison, Cilacap (Verdict, 2018). This fact leads to the next finding, namely that the ISIS group has a complex communication network. It was also later discovered that the main source of this terror act was a message from the leader of the ISIS group in Syria, Abu Bakr Al Baghdadi, who asked his followers to carry out acts of terror immediately. In that edict, $\mathrm{Al}$ Baghdadi called for his followers if they could not go and carry out terror in Iraq and/or Syria, then this action which he called amaliyah could be carried out anywhere, including in Indonesia (Redaksi, 2021).

Aman Abdurrahman caught the message quickly and immediately devised a plan to carry out the orders of the supreme leader. At almost the same time, Saiful Munthohir alias Ahmad Hariyadi alias Abu Gar and Khaidar Ali, who later became key actors behind the ISIS terror attack in Jakarta, came to visit Oman Rachman alias Aman Abdurrahman alias Abu Sulaiman and Iwan Darmawan Muntho eyebrow Rois in Kembang Kuning prison, Nusa Kambangan to convey the plan to carry out the so-called "amaliyah", Aman also welcomed the intention and then conveyed the information above. Aman even directly asked Saiful to be the attack coordinator. Saiful was then able to organize his group and launch attacks in Jakarta (Verdict, 2018).

This shows that the ISIS network in Indonesia had spread rapidly and extended to many areas. As noted in "The Current State of Terrorism in Indonesia: Vulnerable Groups, Networks, and Response", ISIS teachings and movements entered Indonesia mainly through the internet (Fitriani et al., 2018). ISIS terror teachings were then spread in Indonesia by the Indonesian Sharia Activist Forum (FAKSI) through the online media Al-Mustaqbal. This group was founded by Muhammad Fachry in 2013. Since its inception, this group has not only been active in spreading ISIS content, but also sent troops to ISIS headquarters in Iraq 
and Syria, two of whom were Bahrun Syah and Salim Mubarok (IPAC, 2014).

Apart from factions, ISIS in Indonesia is also fully supported by two other groups, namely Tauhid wal Jihad led by Aman Abdurrahman and Jamaah Ansharut Tauhid led by Abu Bakar Ba'asyir. These two groups spread ISIS teachings massively by saying that ISIS is more promising in fulfilling the obligations of carrying out jihad and establishing an Islamic state. Major experts and researchers say that ISIS does carry a new spirit and ideology in terrorism networks. Ali Asghar, for example, said that ISIS was not the same as previous terrorist groups such as $\mathrm{Al}$ Qaeda, which only contained ideology and promises; ISIS emerged as a terrorist group providing evidence. "ISIS jihad is for the establishment of 'Islamic State', while Al Qaeda's jihad is only for Fi sabilillah (in the way of Allah)", wrote Ali (Ashgar, 2016).

To dissect the ISIS network in Indonesia, this study uses a structural gap approach, mainly to look at the role of actors in the network, so that the results of this research can be proposed as one of the bids for preventing terrorism in Indonesia. The structural gap theory was introduced and developed by Ronald $\mathrm{S}$ Burt in Theory of Structural Holes (Burt, 1995). This strategy is developed from the work of Simmel et al. (2009) which refers to a situation when a person can take advantage of conflicts that occur between two or more people in a network, whether business, communication, or otherwise (Mas'udi, 2015).

With the novelty of its teachings and group organization, ISIS grows rapidly in Indonesia. The "success" of ISIS in conquering big cities in Iraq and Syria-although only temporarily - has become a trigger for the spirit of terrorists in Indonesia to do the same thing, that is to establish an Islamic state as an offshoot of ISIS in Indonesia. Supposedly, the dream to make Indonesia an Islamic country is not difficult because this country is inhabited by the largest Muslim population in the world. The terror attack in Jakarta was just the beginning, the attack was then followed by various other similar acts, the two other actions that attracted the most attention-and also become the focus of this article's study-were the terror attacks in two places in Indonesia, namely Poso in Central Sulawesi Province (2016) and in Surabaya and East Java Province (2018).

\section{Methodology}

This research uses mixed methods research (Leech et al., 2010); it is a procedure for collecting, analyzing, and mixing quantitative and qualitative methods in a study or series of studies to understand the research problem. Qualitative and quantitative approaches will be used interchangeably: a quantitative approach will be used to answer questions about the structure of terrorist networks, while a qualitative approach will be used to answer the question of how communication patterns are in the network structure and what factors are the causes of the formation of a terrorist network structure. A qualitative approach will also be used to answer the question of how to model a terrorism prevention strategy based on communication network analysis.

The mixed research design model that will be applied in this research is the 
Explanatory Sequential Mixed Methods Design. According to Creswell, an explanatorily sequential design (also called a two-phase model) consists of first collecting quantitative data and then collecting qualitative data to help explain or elaborate on the quantitative results (Creswell et al., 2004). The intention of this design is to explain qualitative results with qualitative data. To analyze the data finding, this research used a network analysis program based on statistical and isometric calculations called UCINET as one of the software that can be used to manage relational data in communication network analysis. This program was developed by Borgatti with his friends to meet the needs of analysis in the social sciences, especially in network analysis (Hsieh, 2005).

UCINET was chosen because it is relatively easy to use with a wide scope for analysis selection (da Silveira Batista, 2018). Through UCINET, the results sought are classified based on: Density, Centrality Degree, Centrality Betweenness, Centrality Closeness, and Click as described in the design of this research study. After data entry is complete, it then creates sociometric images and sociograms using NetDraw software, this software is one package with UCINET. After the sociometric images and sociograms are presented, then the data is processed using data analysis at the level of actor centrality.

\section{Findings and Discussion}

\subsection{Findings}

\subsubsection{Government Anticipation against ISIS in Indonesia}

Although the government of Indonesia has established the National Counter-Terrorism Agency (BNPT), the counter-terrorism program still leaves a lot of homework. Some parties even say that the government has always been blunt in tackling terrorism. The Habibie Center (THC) in one of its reports highlighted the causes of the dull handling of terrorism in Indonesia, one of which is the unbalanced approach to handling. The state, through its apparatus, is more inclined to use a hard approach through law enforcement rather than a soft approach through a prevention approach. This is seen as ineffective in stopping the growth of radicalism-terrorism (-ism as understanding); the legal approach only succeeded in imprisoning the perpetrator, but not the idea of the perpetrator.

Even if using a soft approach, which focuses more on prevention, prosecution, and de-radicalization; the government's efforts are still often stuck in the recovery section. THC said that the recovery side was not only neglected, but also not carried out optimally. The reason is that the recovery program for convicts.

“...tends to be unsustainable, ad-hoc, and project-oriented. The method used also tends not to depart from strategic planning that takes a short, medium, and long term pattern. In addition, it also does not pay attention to the reality of the needs, skills, and enthusiasm of former terror convicts, only copies ideas and is poor with new ideas, is absent from evaluation and monitoring, and is absent from a pattern of good cooperation and synergy between stakeholders. In addition, the government is considered to have 
not played a major role in social rehabilitation and reintegration initiatives" (Sadarusalam \& Hasan, 2019).

Several government programs in dealing with convicts are also seen by many as less optimal because they are too focused on the side of social reintegration, especially through the disbursement of fresh funds to expatriates. Terrorism, or even to carry out acts of terror again, is still very high (Hendartyo, 2020).

\subsubsection{ISIS Communication Network in Indonesia}

In the other hand, ISIS uses a complex communication network system. In this network, the most important thing is information. Therefore, actors in the network who can make good use of information will be able to reap many benefits. The ability to take advantage of information includes obtaining information, processing information, and disseminating the information to all or part of the desired network members. In a network, the ability to process information is very important for it can be social capital for the actor(s). Rogers and Kincaid define this type of capital as the integration of personal networks (Berto \& Sunarwinadi, 2017) that contain the accumulation of both actual and virtual resources that can provide added value for individuals/groups through mastery or ownership of networks for a long time by establishing relationships so that they are recognized and known, both formally and informally (Monge \& Contractor, 2003).

Burt (1995) mentions that actors in the network can exploit information to make more profits. There are two strategies commonly used by actors (tertius) in the network to gain profits, namely gaudens and iungens. Burt defines tertius gaudens as "the third who benefits" (Burt, 1995). In this context, the tertius actor is not actually involved in the conflict, yet he enters the conflict to take advantage, either by bridging the conflicting parties to make peace or simply to make the conflict longer.

With the holes in the network, the conflicting parties will not be able to communicate directly, they are held back by the hole in their communication network. In this condition, the most important role is needed. This hole arises because actors do not have ties to other actors, both within each other and in different communication networks. This hole provides an opportunity for actors (nodes) who are in between these empty holes to intervene or exploit (Burt, 2005).

In Communication Network Analysis, Eriyanto (2014) said that the Structural Holes acts like a "buffer" that connects two or more contacts that are not connected to each other. He further explained that this theory does not focus on how many networks there are between the ego and the alter, but rather the hole that forms between the relationship between the ego and the alter.

The above strategy was later criticized. One of the experts who launched this criticism is Obstfeld (2005) who offered a second strategy that is very opposite in concept and practice, namely the iungens strategy. For him, third parties cannot only play the role of breaking the network chain but also connecting them. The actors in the network must be connected to each other so that more collabora- 
tion or cooperation occurs in the network. To achieve that goal, the tertiary actor no longer needs to open holes in the network and act as an intermediary in the breaking chain, yet instead closes the holes that exist and facilitates that actor in the network can connect and become network reinforcements (Figure 1).

The two strategies above, as mentioned earlier, are often seen as contradictory strategies. However, research on the ISIS network in Indonesia has shown the opposite fact. Actors in the ISIS network in Indonesia were found to be able to use two network communication strategies interchangeably. Aman Abdurrahman, for example, played the role of gaudens when establishing communication with the highest leadership of ISIS in Iraq and Syria. In this role, he created a hole in the communication network in his group so that all the needs of network members for the highest leader of ISIS in Iraq and Syria had to go through the intercession of Aman as the tertius.

However, Aman Abdurrahman adopted a different strategy when consolidating network members in the Thamrin bombing case. In that case, Aman removed the hole in his network to connect the previously unconnected parties. Aman, based on the facts of the trial, was found to have connected three parties at once, namely; attack planner; Aman Abdurrahman, four executioners in the field; Sunakim Alias Abu Yaza, and Ahmad Muhazin, and funders; Saiful Munthohir alias Ahmad Hariyadi alias Abu Gar. This shows that the two strategies above -even though they are opposites-are in fact very flexible to be used in the field to carry out their terrorist acts.

\section{Discussion}

\subsection{Structural Holes}

To see and then dissect the communication network of the ISIS group in Indonesia, the theory used in this study is the Structural Holes theory. This theory was introduced and developed by Ronald S Burt in Theory of Structural Holes (Burt, 1995, 2005). Some have called this theory as a development of sociological ideas about the benefits of autonomy that can be generated through conflicting affiliations introduced by Simmel et al. (2009) and Merton (1968). In the following years, especially in the 1970s to 1980s, the theory of these two sociologists was developed rapidly, several experts who developed this concept include Burt (2005) with the idea of Structural Autonomy formed from network complexity, Cook and Emerson (1978) through the idea of the power of having partners/partners with an exclusive exchange, Freeman (1977) with the theory of Intermediary Centrality, to Granovetter (1973) through the theory of Weak Ties (Burt, 2005).

The use of Structural Holes analysis to dissect the ISIS network is motivated by the fact that this theory focuses not on the communication network as a whole, but on the role of actors in exploiting the empty holes in the communication network. The Structural Holes is not a natural condition for the actor, that is, it can be created. The actor can create loopholes through which he can take 

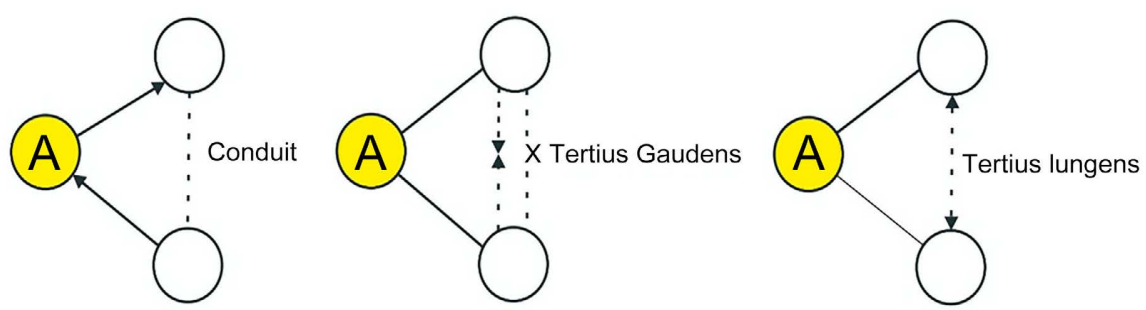

Figure 1. The role of actors in the network (Berto \& Sunarwinadi, 2019: p. 72).

advantage of the network. According to Burt, actors can use two main strategies to ensure their positions are strong and so needed by their alters (Burt, 1995). The two strategies are efficiency and effectiveness. In the first strategy, the ego can create a hole which is then used to enlarge its network. To do this, actors must reproduce alters that are not interconnected or non-repetitive (non-redundant contacts). Meanwhile, with an effectiveness strategy, actors can change alter relations with the aim of making contacts more effective. Here is an illustration of the effectiveness strategy by Burt (Figure 2):

The above figure shows the difference in the number of connections and network patterns in the "before" and "after" conditions. In the "before" condition, the actor (ego) is shown to have only direct contact with the five alters; and not all alters have holes. Actors 1 and 3 are related to each other, as well as actors 4 and 5. In this condition, actors have not been able to play their roles to the fullest. To change conditions, actors can make changes to the alter composition, so that the hole between the networks can be maximized. The actor can release contact with alters number 3 and 5 . Then, ego actor establishes direct contact with alters number 1, 2 and 4 . While alters 3 and 5 that have been released can expand the network. In this condition, actor 3 and 5 remain part of the network because actor 3 still has a relationship with actor 1 . Likewise with actor 5 , he still has direct contact with actor 4 .

\subsection{Connecting the Dots}

Research with a structural hole does not focus on the actor side, yet on the relationships that exist in the network, therefore this research focuses on observing and then analyzing how the relationship works, who is involved in it and what is the role of each actor in the relationship, including getting answers to what the relationship is aiming for (Eriyanto, 2014). However, this study does not deny the role of actors. The focus on relations can also lead researchers to obtain a comprehensive analysis of actors. With this approach, each researcher can get a clearer picture of the actors in their various attributions (individuals, groups, institutions, countries, and so on).

By focusing more on the number and pattern of relationships in the network, a clearer picture of the role of each actor in the network will appear. At the very least, social network analysis can show that the roles and functions of actors in the network are the results of the relationships they have in the network, not the attributions they have. That is, whatever the attribution of the actor, as long as 


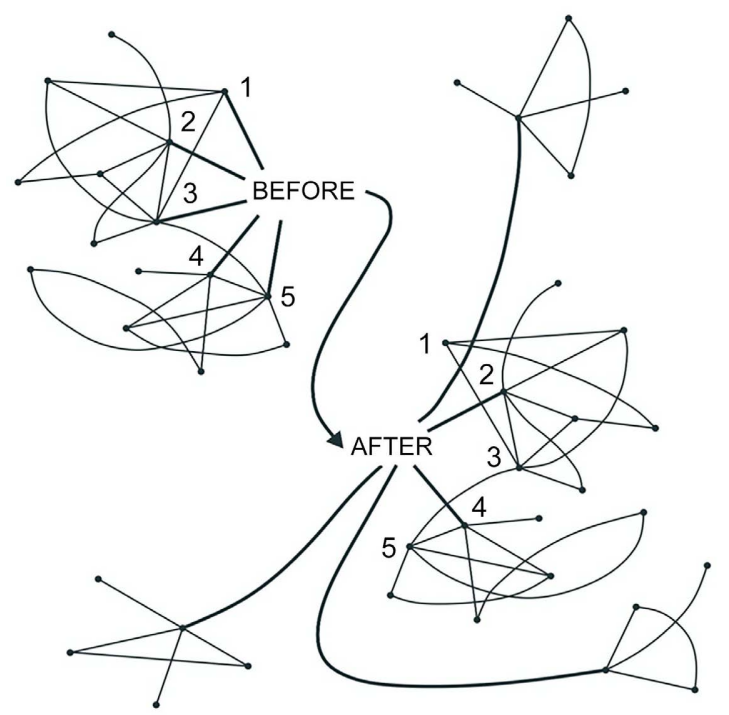

Figure 2. Strategy effectiveness (Burt, 1995).

the actor enters and follows the pattern of relations in the network, he will behave or function according to the direction of the attitude in the network. The reason is that in social networks individuals are never seen as dependent actors, but interdependent (interdependent) with other people (Vera \& Schupp, 2006).

In this study, the main focus is placed on the number and pattern of relationships that exist in the ISIS terrorist group communication network in Indonesia, not on the actors with all their attributions. By focusing more on networks, this study seeks to photograph networks that may be larger than groups. Actors who are in group A, for example, could be connected to a larger network, namely the network that oversees groups A, B, C, and so on. And sure enough, this research finds intersections made by actors in the network; actors cross over to more than one group. This is of course anticipated because actors cannot be placed only as part of certain groups, because when actors establish relationships with other actors or individuals, the relationship can be unlimited. Relationships can propagate to larger groups or networks. Especially with advances in information technology as it is now, expanding the network will only be as easy as turning the palm of the hand (Liao \& Phan, 2015).

\subsection{The Prevention: Integration of Tertius Gaudens and Iungens}

The findings of the intersection of actors in the network above show that there is a novelty in the pattern of relationships that can be carried out by actors in the network. Actors in the network are no longer limited to the roles of "tertius gaudens" and "tertius iungens" only, and that the above two roles are no longer mutually exclusive. The main finding in this study shows that actors can use the above roles interchangeably, depending on the conditions and needs of actors to carry out exploitation in the network. In other words, actors in the communication network of the ISIS terrorist group in Indonesia do not always play their roles rigidly in the network; they can play the role of tertius gaudens, but if 
needed, they can switch roles to tertius iungens.

The different roles played by the actors in the field prove that the iungens and gaudens strategies are not applied rigidly in the field. Elizabeth Long Lingo and Siobhan O'Mahony (2010) have acknowledged this for a long time, saying that gaudens and iungens are not the final choices for online actors. Actors can choose their roles freely, namely to act as gaudens or iungens, depending on the situation and needs (Lingo \& O'Mahony, 2010).

This study shows findings that confirm the above statement. This is shown by the different roles played by Aman Abdurrahman, one of which was in the case of the bomb attack in Thamrin, Jakarta. In this case, Aman Abdurrahman plays the roles of tertius iungens and tertius gaudens alternately. When giving instructions to Saiful Munthohir alias Ahmad Hariyadi alias Abu Gar to carry out ISIS "amaliyah" in Indonesia, Aman played the role of tertius gaudens. In carrying out this role, Aman broke the communication chain between Abu Gar as a member of the Indonesian ISIS group and other ISIS network members in Iraq and Syria who gave orders to carry out amaliyah. By breaking Abu Gar's communication chain with the ISIS network at the head office, Aman can control the flow of information because he is a buffer on this network.

This study also found that Aman Abdurrahman only played a role as a gaudens for the ISIS group in Jakarta, because when he built a network with the ISIS group in Poso (with the East Indonesia Mujahidin group [MIT]), Aman Abdurrahman played the role of tertius iungens, especially to Santoso. Aman opened up a lot of access to Santoso so he was able to quickly build and grow the MIT group. However, Santoso apparently did not use the same communication pattern when dealing with his subordinates. He prefers to play the tertius gaudens role when communicating with his group members at MIT. This pattern was later followed by his successors in the MIT group from Ali Kalora, Daeng Koro, to Basri. Generally, the role as breaker (gaudens) is carried out for the purpose of maintaining the authority of the leadership as well as the sacredness of the line of command. Aman played this role in the context of cutting off the lines of communication that would allow his men to communicate directly with the top leader of ISIS, Abu Bakr al-Baghdadi.

In the findings of the case above, Tertius can still make profits; or can still be the "third party who laughs" even though the roles played in the network often change (Monge \& Contractor, 2003). Tertius had at least three advantages, first, access; actors still get information that other parties cannot, which means, actors still have the capital to increase their social capital in the network. Second, control of alter; actors can still control the types of information and determine to whom the information will be given. Third, become the focus of information; the actor still has an important position in the network because he has access and control over the type and rate of information circulation in the network, therefore he will still enjoy the benefits of being a reference for his group members. The following is an image to explain the information rate in a network that uses the two-tertius integration pattern (Figure 3): 


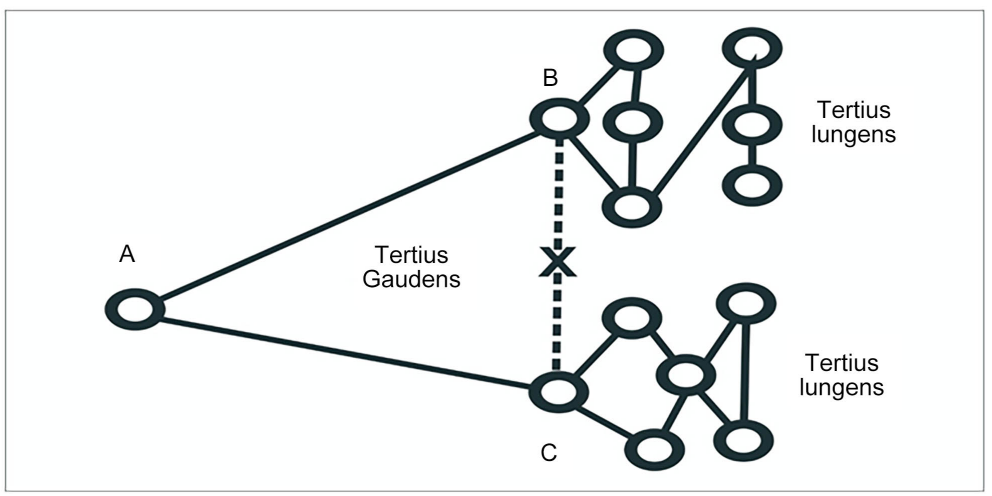

Figure 3. Two tertius integration.

The figure above shows the flexibility possessed by the tertius actor (A) to determine what strategy will be used in a particular network group. Of course, the actor must fully understand the conditions and needs of the group in question so that he can use the right approach to then extract as much profit as possible from the network. The greatest actor may, for example, play the role of iungens by connecting all alters in the networks he enters ( $\mathrm{B}$ and $\mathrm{C}$ ), but with the high social capital he has, actor A can also break (gaudens) or open a hole between network B. and C, so these two networks will depend on actor A in terms of exchanging information or access.

\section{Conclusion}

The Indonesian government (State Intelligence Agency and the National Counter Terrorism Agency) can play the role of tertius who stands in an integrated position to exploit the flow of information in the ISIS network in Indonesia in the context of preventing terrorism. In this context, as tertius, the government can carry out its function in fewer than two conditions, namely: when there is competition between two parties fighting for the same information, the tertius can act as controller by determining who will be given the information. Second, if both parties are in a conflict position, tertius can change the role of being a mediator whose function is to find a resolution to reduce conflict and share information as much as possible according to their respective portions.

As a tertius, the government can also use former members of terrorist groups to carry out their functions as gaudens in their former groups, namely by directing former combatants or terrorists to cut off the lines of communication that existed in their former groups. That way, members of the terror group cannot communicate effectively, the line of command is cut off, and the terrorist group weakens by itself. The next challenge is to ensure that people whose communication lines in terror groups have been cut off can be immediately intervened so that they leave the group and return to the right path. For this task, the government can play the role of tertius iungens, namely by reconnecting their lines of communication with moderate-nationalists. In this case, the government can maximize the de-radicalization program. 


\section{Conflicts of Interest}

The authors declare no conflicts of interest regarding the publication of this paper.

\section{References}

Ansori, M. H., Rasyid, I., Arif, M., Peranto, S., Efendi, J., \& Hutagalung, V. (2019). Memberantas Terorisme di Indonesia: Praktik, Kebijakan dan Tantangan. The Habibie Center.

Ashgar, A. (2016). Gerakan Terorisme tahun 2015: Pola Serangan, Jumlah Korban, dan Wajah Baru Global Jihad. Jurnal Keamanan Nasional, Pusat Kajian Keamanan Nasional Universitas Bhayangkara Jakarta Raya, 2, 1-18. https://doi.org/10.31599/jkn.v2i1.35

Berto, A. R., \& Sunarwinadi, I. R. S. (Eds.) (2017). Are the Structural Holes a Form of Social? A Theoretical Debate. In A. R. Berto, \& I. R. S. Sunarwinadi (Eds.), International Conference on Administrative Science, Policy and Governance Studies (ICAS-PGS) (pp. 353-360). Atlantis Press. https://doi.org/10.2991/icaspgs-icbap-17.2017.44

Berto, A. R., \& Sunarwinadi, I. R. S. (2019). The Holes in Structural Holes Theory (A Literature Review). Social and Humaniora Research Symposium (SoRes 2018), Atlantis Press. https://doi.org/10.2991/sores-18.2019.16

Burt, R. S. (1995). Structural Holes: The Social Structure of Competition. Harvard University Press.

Burt, R. S. (2005). Brokerage and Closure: An Introduction to Social Capital. Oxford University Press.

Cook, K. S., \& Emerson, R. M. (1978). Power, Equity and Commitment in Exchange Networks. American Sociological Review, 43, 721-739. https://doi.org/10.2307/2094546

Creswell, J. W., Fetters, M. D., \& Ivankova, N. V. (2004). Designing a Mixed Methods Study in Primary Care. The Annals of Family Medicine, 2, 7-12. https://doi.org/10.1370/afm.104

da Silveira Batista, H. M. C. (2018). Análise de Redes Sociais: Metodologia de apoio ao mapeamento científico (Portuguese ed.). Tapa blanda.

Eriyanto (2014). Analisis Jaringan Komunikasi: Strategi Baru dalam Penelitian Ilmu Komunikasi dan Ilmu Sosial Lainnya. Kencana.

Fenton, A., \& Price, D. (2016). ISIS, Jihad and Indonesian Law: Legal Impacts of the January 2016 Jakarta Terrorist Attacks. Issues in Legal Scholarship, 14, 1-26.

https://doi.org/10.1515/ils-2016-0255

Fitriani, A. S., Putri, P., Sari, N., \& Adriana, R. (2018). The Current State of Terrorism in Indonesia: Vulnerable Groups, Networks, and Responses. Center for Strategic and International Studies.

Freeman, L. C. (1977). A Set of Measures of Centrality Based on Betweenness. Sociometry, 40, 35-41. https://doi.org/10.2307/3033543

Granovetter, M. S. (1973). The Strength of Weak Ties. American Journal of Sociology, 78, 1360-1380. https://doi.org/10.1086/225469

Hsieh, H. F., \& Shannon, S. E. (2005). Three Approaches to Qualitative Content Analysis. Qualitative Health Research, 15, 1277-1288. https://doi.org/10.1177/1049732305276687

IPAC (Inter-Parliamentary Alliance on China) (2014). The Evolution of ISIS in Indonesia. Report No.13, Inter-Parliamentary Alliance on China.

Leech, N. L., Dellinger, A. B., Brannagan, K. B., \& Tanaka, H. (2010). Evaluating Mixed Research Studies: A Mixed Methods Approach. Journal of Mixed Methods Research, 4, 17-31. https://doi.org/10.1177/1558689809345262 
Liao, Y.-C., \& Phan, P. H. (2015). Internal Capabilities, External Structural Holes Network Positions, and Knowledge Creation. The Journal of Technology Transfer, 41, 1148-1167. https://doi.org/10.1007/s10961-015-9415-x

Lingo, E. L., \& O’Mahony, S. (2010). Nexus Work: Brokerage on Creative Projects. Administrative Science Quartely, 55, 47-81. https://doi.org/10.2189/asqu.2010.55.1.47

Mas'udi, M. (2015). Akar-Akar Teori Konflik: Dialektika Konflik; Core Perubahan Sosial dalam Pandangan Karl Marx dan George Simmel. Fikrah, Jurnal Ilmu Aqidah dan Studi Keagamaan, 3, 177-200.

Merton, R. K. (1968). Social Theory and Social Structure. The Free Press.

Monge, P. R., \& Contractor, N. S. (2003). Theories of Communication Networks. Oxford University Press. https://doi.org/10.1093/oso/9780195160369.001.0001

Obstfeld, D. (2005). Social Networks, the Tertius Iungens Orientation, and Involvement in Innovation. Administrative Science Quartely, 50, 100-130.

https://doi.org/10.2189/asqu.2005.50.1.100

Sadarusalam, B. W. A., \& Hasan, K. (2019). Kontra Propaganda Badan NasionalPenanggulangan Terorismedalam Menanggulangi Perkembangan Radikalisme di Indonesia. The Indonesian Journal ff Politics and Policy (IJPP), 1, 74-82. https://doi.org/10.35706/ijpp.v1i1.1648

Simmel, G., Blasi, A. J., Jacobs, A. K., \& Kanjirathinkal, M. J. (2009). Sociology: Inquiries into the Construction of Social Forms. Koninklijke Brill NV.

Speckhard, A. (2020, April 15). Is Internet Recruitment Enough to Seduce a Vulnerable Individual into Terrorism. Homeland Security Today.

Vera, E. R., \& Schupp, T. (2006). Network Analysis in Comparative Social Sciences. Comparative Education, 42, 405-429. https://doi.org/10.1080/03050060600876723

\section{Others}

Hendartyo, M. (2020, Noember 2). Kemensos Salurkan Bantuan Rp 1,2 M untuk Eks Napi Terorisme.

https://nasional.tempo.co/read/1401682/kemensos-salurkan-bantuan-rp-12-m-untuk-e ks-napi-terrorism/full\&view $=$ ok

Redaksi, T. (2021, March 21). Akar Sejarah Jamaah Ansharut Daulah: Niat Aman Abdurrahman Mendirikan Khilafah.

https://voi.id/memori/41490/akar-sejarah-jamaah-ansharut-daulah-niat-aman-abdurra hman-mendirikan-khilafah

Verdict (2018). Court 140/Pid.Sus/2018/PN.Jak.Sel 